\title{
ÉPICA, LÍRICA E TRAGÉDIA NAS ARGONÁUTICAS DE APOLÔNIO DE RODES
}

\author{
Guilherme Gontijo Flores*
}

Resumo: This article intends to present a brief analysis of Apollonius Rhodius' Argonautica 3. 956-1007 - the meeting of Jason and Medea as well as Jason's first speech - and to determine how the crossing of literary genres (Kreuzung der Gattungen) can be traced in a allusive texture that demands from its reader the knowledge of other works written in different genres (such as the Pindar's coral and Sappho's monadic lyric, and Euripides' Medea) besides the many Homeric formulas. In such a generic clash, a refined building of ironical misreadings slowly unveils itself with much more than a mere empty literary technique of Hellenistic taste.

Palavras-chave: Apolônio de Rodes, Cruzamento de Gêneros, Ironia, Poesia Helenística.

A complexidade da criação literária das Argonáuticas de Apolônio de Rodes, para além de uma narrativa condensadíssima em sua brevidade, é formada por uma vasta trama de intertextualidades, que vão da mera alusão literária ao diálogo cerrado com outras obras. Essa série de diálogos travados por Apolônio, mais do que capaz de promover uma poética de cruzamento de gêneros - Kreuzung der Gattungen, hoje termo tão batido nos estudos de poesia helenística -, é capaz de realizar uma obra que oferece "camadas" de leitura que passam do entendimento imediato dado pela narrativa seqüencial até uma necessária desleitura provocada pelos choques entre variantes míticas, mas sobretudo pelos silêncios significativos presentes em todo o texto.

O fato de não se tratar de uma épica estritamente homérica, ou de filiação genérica pura (e daí Kreuzung der Gattungen), já pode ser notado a partir do sétimo verso do poema, quando sabemos que o Rei Pélias recebera um oráculo de que seria aniquilado por um homem de uma só sandália (7 oio $\pi \varepsilon ́ \delta \imath \lambda o v)$, uma justificativa para a viagem de Argos que já aparece na famosa quarta pítica de Píndaro, em que vemos o mesmo Jasão aparecer no oráculo também com apenas

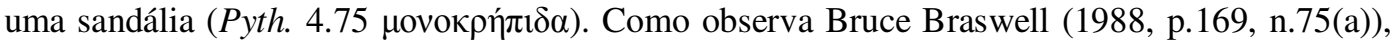

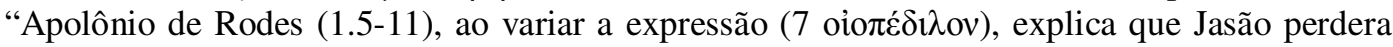
sua sandália enquanto cruzava o Anauro", e assim o estudioso conclui que a figura da "monossandália" provavelmente já deveria aparecer nas versões mais antigas do mito ${ }^{1}$ O interesse pela quarta pítica não poderia passar despercebido; trata-se exatamente de um dos poemas líricos mais épicos em estilo, além de tratar especificamente da viagem de Jasão na maior parte de seus versos. Por isso mesmo, talvez nessa primeira passagem, ao dialogar com uma ode que cruza o gênero para almejar a narrativa de tom épico, Apolônio já aponte de que modo pretende fazer o movimento contrário em sua obra: ou seja, desfazer parte das expectativas épicas estabelecidas pelo cânone homérico para englobar outros gêneros, tais como aspectos da lírica coral pindárica, da lírica monódica de Safo e, obviamente, da Medéia de Eurípides.

De modo similar, na abertura do terceiro canto, o poeta faz uma invocação a Érato (provavelmente também a musa inominada, $\theta \varepsilon \alpha ́$, Moṽ $\alpha$, que aparece na abertura do quarto canto):

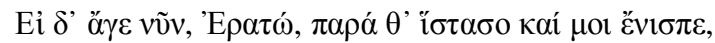

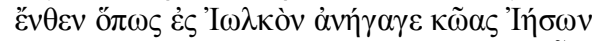

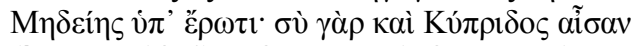

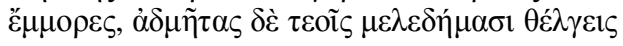

\footnotetext{
"Professor da área Letras Clássicas da Universidade Federal do Paraná (UFPR).

${ }^{1}$ Embora Apolônio varie o termo em relação à sua primeira aparição em Pyth. 4.75, o termo usado por Píndaro no verso 96 é $\pi \varepsilon ́ \delta 1 \lambda \circ v$.
}

Organon, Porto Alegre, no 49, julho-dezembro, 2010, p.111 - 128 


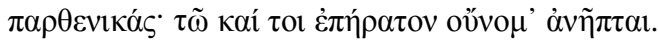

\begin{abstract}
Agora ajuda-me, Érato, e por fim me conta como foi que Jasão levou o velo a Iolcos com o amor de Medéia; pois tu compartilhas os poderes da Cípria e encantas com angústias as virgens: daí tiras teu amável nome (Arg. 3.1-5).
\end{abstract}

A nova invocação no meio da obra, além da invocação inicial a Febo (1.1-4) como já notara Richard Hunter, "é uma marca auto-consciente da diferença entre Apolônio e Homero; na Ilíada e na Odisséia apenas o primeiro livro começa com uma invocação" (1989, p. 95). Essa ruptura genérica é ainda acompanhada pela nomeação da musa, Érato, que à primeira vista parece pouco cabível a uma narrativa épica, por estar ligada às paixões amorosas, como se poderia depreender

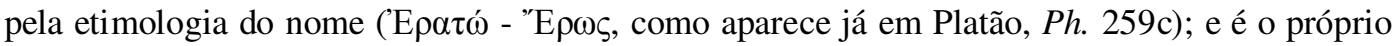
poeta quem ressalta seu poder com o termo ép $\omega \tau$ do terceiro verso, além de revelar sua proximidade com Afrodite (a Cípria, v. 3) e o seu poder encantatório sobre as virgens em geral. Por fim, explicitando o jogo etimológico, Apolônio diz ser daí que Érato tira seu nome, e faz mais um jogo com o adjetivo غ̇лท́ $\alpha \tau o v$, que altera oủvo $\mu \alpha$, o próprio nome da divindade, trecho que ressoa em Ovídio Ars. am. 2.16 (nunc Erato, nam tu nomen Amoris habes). O que se percebe neste momento da narrativa, portanto, não é a simples quebra de expectativa com o gênero épico por causa da nova invocação em começo de canto, mas também uma mudança temática, uma incorporação importante do assunto amoroso dentro da poesia épica ${ }^{2}$. Não que a poesia de homérica se esquivasse do amor, ou o excluísse da economia narrativa; ao contrário, temos Helena e Páris, Odisseu e Penélope, Nausícaa, Calipso, Circe; temos também os deuses Zeus e Hera, Afrodite e Ares, dentre outros; porém tal temática amorosa nunca toma o centro da narrativa e permanece sempre, de certo modo, marginal. Se tivéssemos que dar uma definição do gênero que mais abraça a temática amorosa, creio que nenhum tomaria o lugar da lírica, e ao apontar para o tema amoroso, Apolônio começa também a indicar o gênero lírico - a quebra de expectativa também se revela uma possibilidade de rumos; o cruzamento de gêneros inicia a revelação de um novo paradigma de épica, bem como de herói épico. Caberia, entretanto, ao leitor perceber que esse tema vinha sendo anunciado desde a descrição do manto de Jasão (1.721-768) por oposição ao escudo de Aquiles (Il. 18.478-608), já que a "arma"de Jasão nada tem de bélica, mas exerce um poder de sedução sobre Hipsípile e as mulheres de Lemnos; ou desde a cena da perda homoerótica de Héracles, no episódio de Hilas $(1.1240-1362)^{3}$, que resulta na saída do herói de perfil mais homérico, abandonado pela tripulação no momento em que se entrega ao desespero amoroso gerado pela perda de seu amado. Por fim, as alusões à tragédia de Eurípides são tantas, que a simples referência, mais adiante, ao solilóquio da Medéia de Apolônio já bastaria para estabelecer um longo discurso na construção da personagem feminina (3.744-824):

Há muitas coisas envolvidas aqui: um reconhecimento de dívida literária e do fato de Medéia ter se tornado, acima de tudo, uma personagem teatral; uma mistura inovadora entre os gêneros épico e trágico; a natureza "trágica" na apresentação de Apolônio e o fato de os eventos da épica eventualmente resultarem numa grande ação "trágica". A Medéia de Eurípides relata eventos muito posteriores à expedição argonáutica, porém Apolônio prevê em seus leitores um

\footnotetext{
${ }^{2}$ Hunter ainda aponta para o jogo sonoro do pedido de proximidade da Musa invocado pelo termo $\pi \alpha \rho \dot{\alpha}$ no primeiro verso de

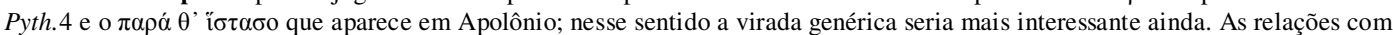
a narrativa dos argonautas na Lide de Antímaco também não devem ser deixadas de lado. Sabemos também da importância da Naupactica de Eumelo e das Cólquidas de Sófocles, mas as obras só nos chegaram através de fragmentos nos escólios. Por fim, mas não menos interessante, o segundo verso alude com muita semelhança o frag. 11 de Mimnermo (Cf. Vian, 2002).

${ }^{3}$ Como referência importante a Pind. Pyth. 4, não podemos nos esquecer do catálogo dos argonautas (vv. 169-87), construção tomada de empréstimo da épica, mas que influencia, também pela sua brevidade, o catálogo um pouco mais alongado e completo de Apolônio (Cf. Braswell, 1988, p. 247-8), o que faz com que o próprio catálogo tenha dupla influência épica e lírica; além da probabilidade de Apolônio tirar o número de 50 argonautas do verso 245 da mesma ode e da importância dada por Píndaro ao poder de persuasão amorosa de Jasão.
} 
conhecimento íntimo dessa peça famosa, e sua ação paira sobre as Argonáuticas, mesmo quando não é especificamente mencionada (Hunter, 1989, p. 18).

No entanto, não pretendo aqui tornar ao assunto das fontes de Apolônio, já bastante estudado; busco uma breve leitura do encontro entre Jasão e Medéia e da primeira fala de Jasão para a princesa, no terceiro canto (3.956-1007). Meu intuito será, portanto, não o de identificar todos os ecos literários importantes que aparecem no trecho em questão, mas o de analisar de que modo esse entrelaçar genérico, somado aos previamente citados "silêncios" do texto, sugere uma estrutura que chamarei de irônica. Vejamos o trecho:

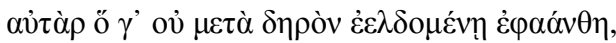

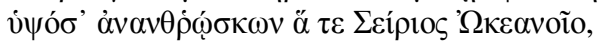

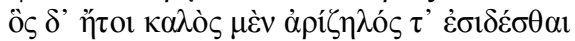

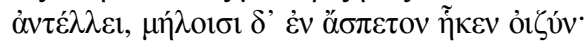

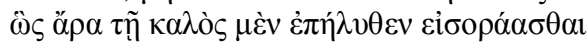

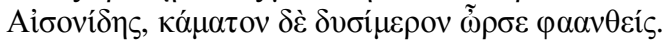

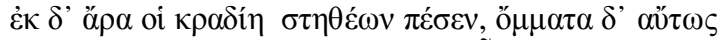

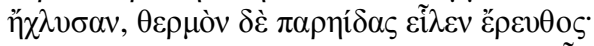

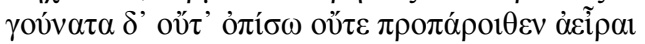

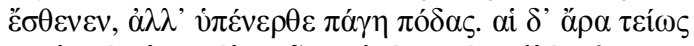

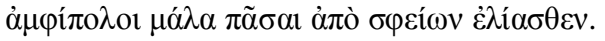

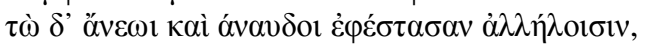

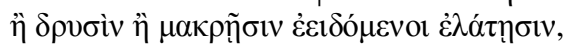

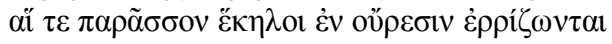

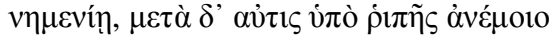

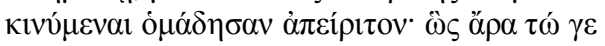

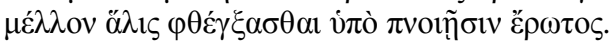

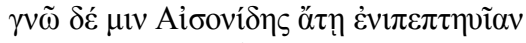

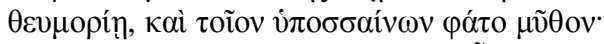

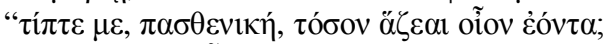

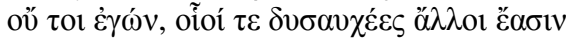

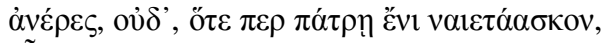

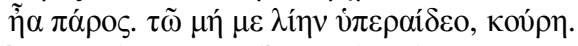

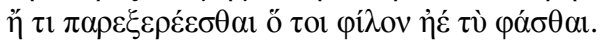

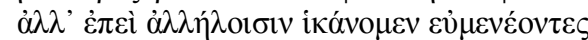

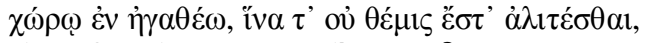

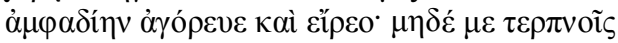

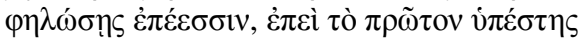

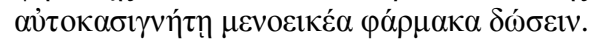

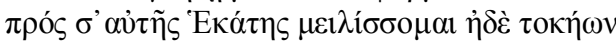

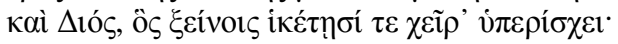

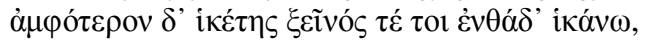

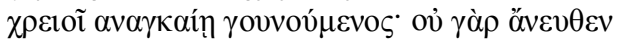

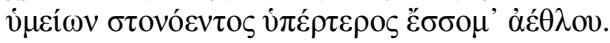

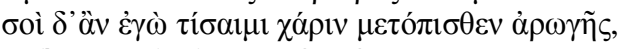

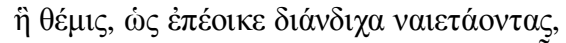

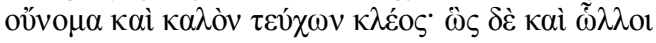

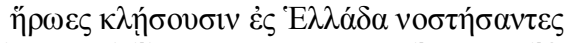

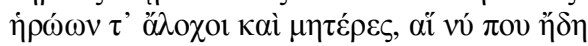

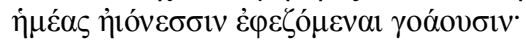

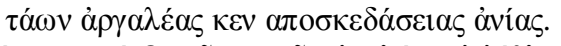

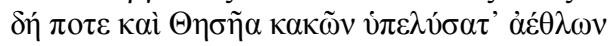

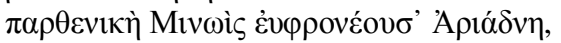
ฑ̄

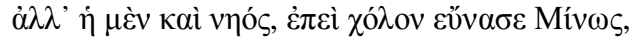

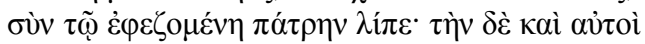

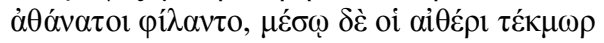




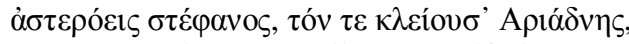

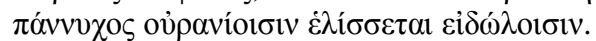

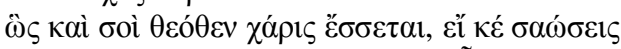

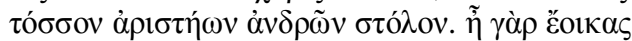

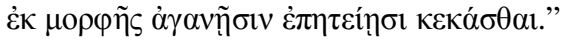

Mas ele sem demora brilha à desejosa como alta estrela surge Sírio do Oceano, que fulgurante e bela de se ver se eleva e traz inumeráveis prantos ao rebanho; assim, belo ao olhar, enfim chegou-se a ela Jasão: seu brilho atiça indesejável dor. Desaba o coração da moça; os olhos são só névoa; um cálido rubor lhe toma as faces; os joelhos fraquejam, sem à frente e atrás;

e abaixo estão seus pés pregados. Nesse instante as servas todas se afastaram do casal.

Ficaram mudos, em silêncio, olhando o outro, parecendo carvalhos ou dois altos pinhos, que, imóveis lado a lado, têm raiz nos montes em calma, mas que ao toque de uma brisa causam um estrépito imenso; e estavam na iminência de muita fala à força dos sopros do Amor.

O Esônide notou que ela caíra numa fatídica desgraça, e sedutor falou:

"Por que me temes, virgem, se eu estou sozinho? Eu não teço a vanglória insolente dos outros homens; nem antes, quando eu habitava a pátria, tecia. Então controla o teu pudor, menina, de questionar ou de dizer o que desejas.

Mas, como aqui viemos com benevolência a um santuário, onde não convém pecar,

fala e pergunta abertamente: não me enganes com falas agradáveis, se antes prometeste à tua irmã de dar-me a droga necessária. Imploro-te por Hécate, pelos teus pais,

por Zeus, que guarda os suplicantes e estrangeiros: como estrangeiro e suplicante eu venho a ti, necessitado, de joelhos; pois sem vós eu não supero o doloroso desafio.

Depois eu pagaria a graça desta ajuda, e, como bem convém a quem mora distante, te daria renome e bela glória, e também outros heróis, ao retornar à Grécia; e as mães e esposas desses heróis te louvarão, que neste instante sentadas pela praia choram nossa vinda, quando acabares com a angústia que as devora. Pois libertou Teseu de um cruel desafio virgem, prole de Minos, prudente Ariadne, que Pasífae, filha de Hélio dera à luz.

Assim que Minos se acalmou; sentou no barco e junto ao jovem deixa a pátria: foi amada por deuses imortais, e no céu o seu signo, a coroa estrelada de nome Ariadne, circula a noite inteira entre as contelações. Também terás a graça divina, se salvas esta tropa de grandes homens. E, a julgar

por tua beleza, sei que exceles na bondade" (Arg. 3.956-1007).

Organon, Porto Alegre, no 49, julho-dezembro, 2010, p.111 - 128 
A descrição inicial do aparecimento de Jasão invoca imediatamente a cena anterior em que ele se aproxima do palácio de Hipsípile (1.774-81), quando é comparado à estrela da tarde, por seus elos com a celebração nupcial e, portanto, com a atividade sexual representada pelo himeneu; mas, além de evocar uma cena anterior interna à obra, o símile também aponta para uma famosa cena da Ilíada em que Príamo observa Aquiles pouco antes de este se encontrar com Heitor para o combate:

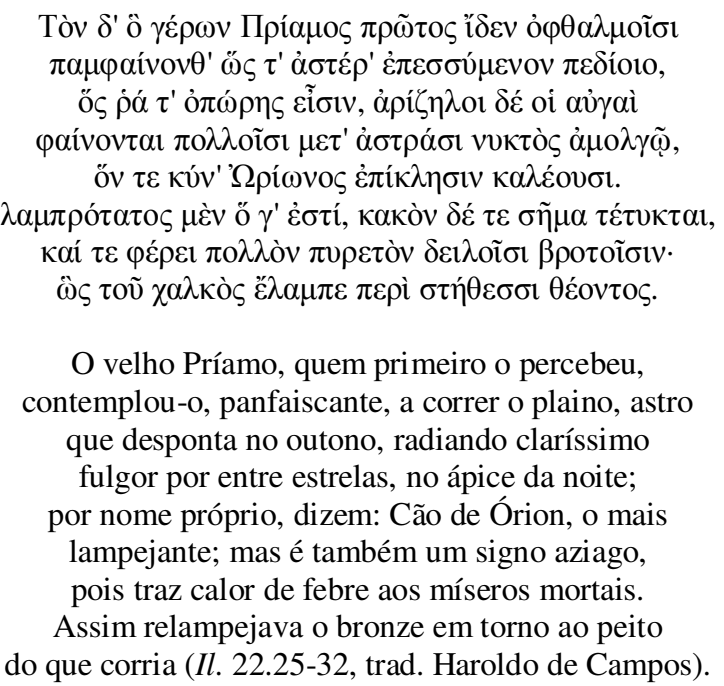

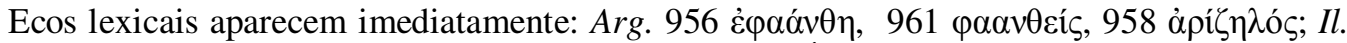

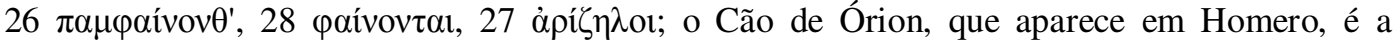
própria estrela Sírio - parte da constelação de Cão Maior (Canis maior). A referência natural à qual os dois poetas fazem é ao período da canícula, entre junho e agosto, um período bastante quente em que a constelação brilha mais, fazendo com que os antigos acreditassem que o calor seria decorrente do brilho dessas estrelas; no período de julho, portanto, segundo os antigos, as doenças afligiriam mais os homens, e as mulheres ficariam mais impudicas, ou ansiosas, o que cai bem tanto para o símile do gado sendo desolado quanto para o comportamento de Medéia. Nos dois símiles, há um contraponto entre a beleza de Aquiles/Jasão e seu respectivo poder destrutivo: no caso de Aquiles, o resultado é a morte de Heitor, que se dará ainda no canto 22, fato que demonstra a destruição específica que será levada sobre Príamo, que por sua vez perderá simultaneamente seu filho e seu melhor combatente na defesa das muralhas de Tróia. No caso de Jasão, nós ficamos confusos: a cena imediata não traz nenhuma destruição para Medéia. Esse é o primeiro silêncio da passagem: o narrador omite que a oposição beleza/destruição em Jasão não vai ocorrer durante a narrativa - seu poder destrutivo aponta para fora, aponta para o mito e muito provavelmente para tragédia de Eurípides. Mais ainda, a destruição provocada por ele se mostra sutil na reação física de Medéia (vv. 962-5), que por sua vez responde às reações físicas similares por que passara Medéia no estágio progressivo de sua paixão ao ver Jasão (3.288-90 e 724-6); além dos ecos internos que conferem um movimento constante à narrativa, é inevitável perceber a reconstrução da famosa passagem de Safo citada por Longino em Do sublime:

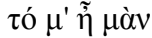

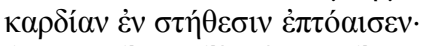

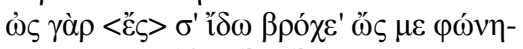

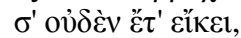

$$
\begin{aligned}
& \dot{\alpha} \lambda \lambda \grave{\alpha} \dagger \kappa \alpha \mu \dagger \mu \grave{\varepsilon} \nu \gamma \lambda \tilde{\omega} \sigma \sigma \alpha \dagger{ }^{\prime} \alpha \gamma \varepsilon \dagger, \lambda \varepsilon \dot{\varepsilon} \pi \tau \mathrm{\sigma}
\end{aligned}
$$

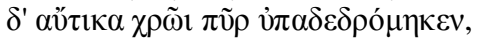




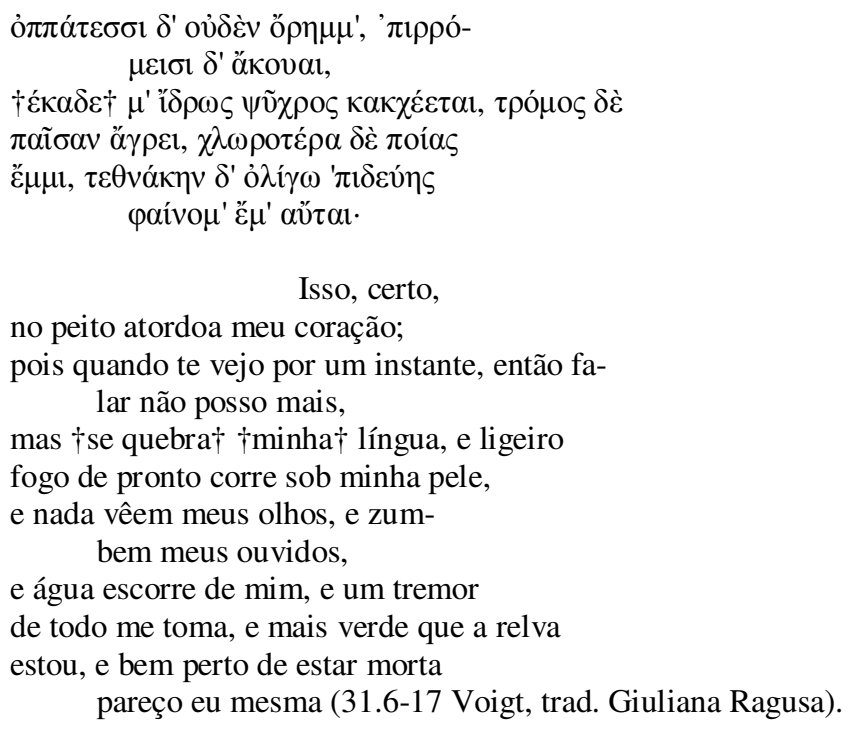

A semelhança vocabular inicial também torna a construção mais elaborada (Arg. 3.962,

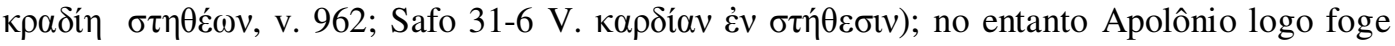
dos ecos lexicais e trabalha sobre as idéias da descrição física apresentada por Safo: seguindo a

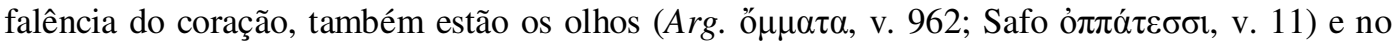
lugar do fogo $(10 \pi \tilde{v} \rho)$ que toma a pele da poetisa, temos (no ponto de vista da ainda virgem

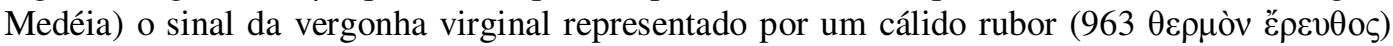

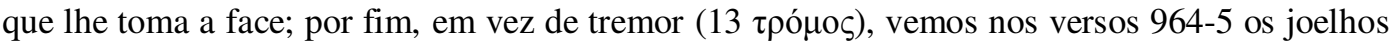
e os pés perdendo seus movimentos, numa metonímia da perda de controle motor total por parte de Medéia. Depois dessa série de semelhanças, parece-me impossível esquecer que o termo que abre o poema de Safo não é outro, senão paíveđaí, e o retorno especular sobre o eu-lírico se fecha com o mesmo verbo na primeira pessoa do singular paívoual (v. 17), enquanto vemos no texto das Argonáuticas, como já demonstrei, o recurso da série etimológica é $\varphi \alpha \alpha ́ v \theta \eta \eta$

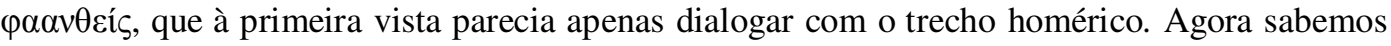
que os termos não eram fortuitos, mas desde o princípio preparavam a alusão lírica à poesia de Safo, com a temática da aparição/aparência/fulgor de Jasão. A imobilidade de Medéia logo é expandida (à guisa de suspense narrativo) para o casal parado, estanques, diante um do outro, como altos pinhos; no entanto, pelo desenvolvimento do segundo símile, sabemos que o amor será capaz de em breve sacudi-los, o que nos remete mais uma vez a um famoso fragmento de $\mathrm{Safo}^{4}$ :

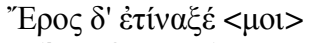

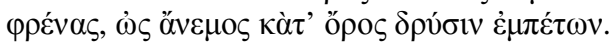

$$
\begin{aligned}
& \text { Amor sacudiu minhas } \\
& \text { entranhas, feito brisa no monte caindo sobre as árvores (47 Voigt). }
\end{aligned}
$$

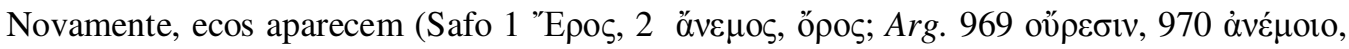
972 ह̌ $(\omega \tau$ ) $)$, e podemos ver mais uma encenação do poder destrutivo do Amor, que aqui fará com que os dois quebrem o silêncio. Ironicamente, o silêncio é provocado pelo amor, mas, uma vez quebrado também por ele, levará ao desfecho trágico que se encena. O que não se pode deixar de notar, ao retornarmos ao começo desta reflexão é que, diferentemente de Príamo, Medéia, tomada de amor, não consegue perceber a parte nefasta do brilho causado pelo herói; é

${ }^{4} \mathrm{O}$ reaparecimento de Safo não deve nos surpreender se lembrarmos que ela é considerada como a poeta lírica par excellence no período helenístico, principalmente com a temática amorosa, muito embora pudéssemos tecer comparações também com a poesia de Álcman, Íbico, Anacreonte e Arquíloco (Cf. Hunter, 1989, p. 27).

Organon, Porto Alegre, no 49, julho-dezembro, 2010, p.111 - 128 
nessa ignorância de Medéia, criada pela conexão lírica operada por Apolônio, que se aponta o trágico $^{5}$. Essa marca trágica, entretanto, se, por um lado, é cuidadosamente criada pelo autor, por outro é completamente silenciada pelo narrador, que nada refere neste ponto sobre o futuro de Medéia, ou sobre o sentido do brilho nefasto de Jasão, deixando para o leitor sua interpretação ${ }^{6}$.

Mas o silêncio narrativo persiste, e na fala de Jasão o leitor tem uma nova surpresa. Como nos informa Apolônio (973-4), Jasão percebe o desespero de Medéia - o termo homérico ö́n

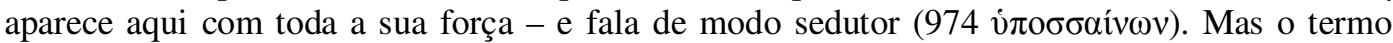

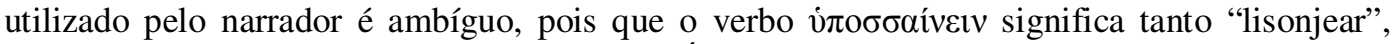
"falar de modo agradável" quanto "enganar". É no limite entre esses dois sentidos que transita

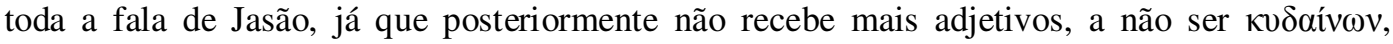
praticamente um sinônimo, porém que pouco explicita o sentido do particípio anterior. Mas essa ambigüidade não é mera confusão. Como atenta Hermann Fraenkel sobre a escrita de Apolônio, "por mais abstrusa, ele tem coisas bem definidas a dizer. Que coisas são essas, só podemos definir com uma interpretação minuciosa" (1952, p. 144). Sigamos, portanto, na trilha formada pela fala de Jasão.

Em primeiro lugar, o herói faz questão de se diferenciar dos outros homens, que poderiam buscar seduzir Medéia: ele não a procura para poder narrar seus sucessos amorosos, como

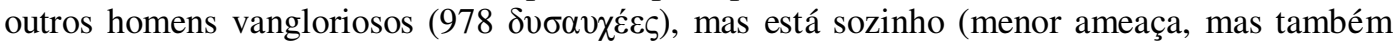
ausência de testemunhas), e portanto pede que ela largue seu pudor exagerado de virgem (979

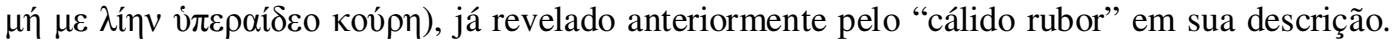

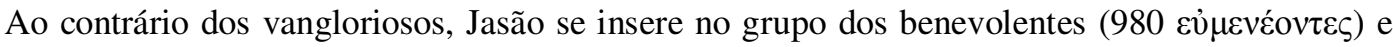

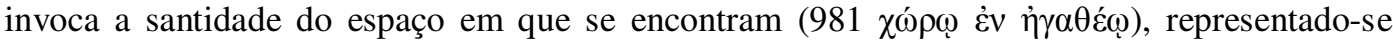
afinal como homem pio e honrado. O resultado dessa preparação é o pedido invertido para que

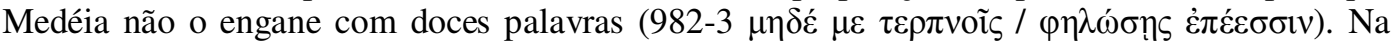
seqüência, Jasão, aproveitando a temática religiosa, descreve-se como um estrangeiro suplicante

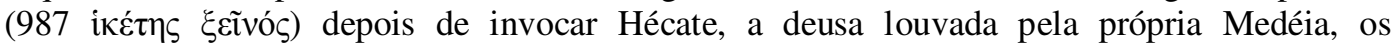
familiares de Medéia (o que insere a figura de Hélio, o deus Sol, avô da virgem) e termina em Zeus, o pai dos deuses, num movimento crescente de vai do louvor pessoal de Medéia (Hécate), passando pelos antepassados familiares (Eetes e Hélio) para desaguar na piedade cósmica representada por Zeus, sobretudo como patrono dos estrangeiros e dos suplicantes. Os dois versos que fecham essa série são ainda reforçados pela estrutura quiástica dos adjetivos:

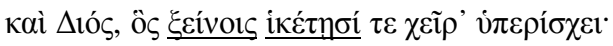

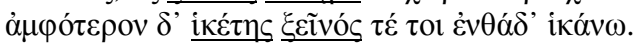

por Zeus, que guarda os suplicantes e estrangeiros:

como estrangeiro e suplicante eu venho a ti $\mathrm{i}^{7}$ (Arg. 986-7).

Como agradecimento de estrangeiro, Jasão ainda promete agraciá-la como renome e bela

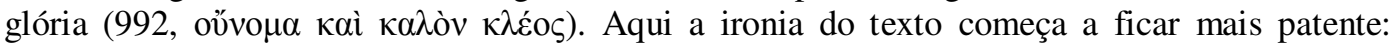
sabemos que o nome de Medéia é bastante famoso, não podemos negar sua fama, mas não se

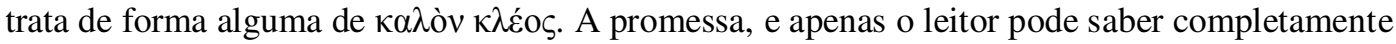
(já que o narrador pouco menciona sobre as intenções de Jasão), não vai se cumprir de todo, mas apenas no quesito fama. O silêncio do narrador e de Jasão muito se assemelha ao do

${ }^{5}$ É curioso notar a ironia entre a figura de Medéia que aparece em Píndaro como detentora de um saber sobre o futuro em sua profecia (Pyth. 4.13-56) e a outra que aqui é incapaz de perceber um vislumbre do seu próprio futuro.

${ }^{6} \mathrm{O}$ diálogo entre Jasão e Medéia ainda parece responder ironicamente à afirmação de Heitor, pouco adiante no mesmo canto (Il.

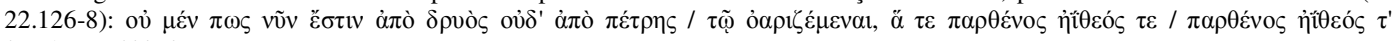

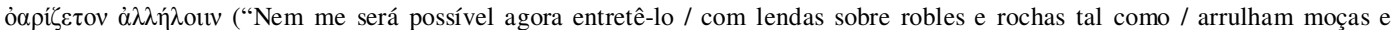
rapazes, uns aos outros, / uns aos outros, rapazes e moças arrulham", trad. Haroldo de Campos). Aqui é exatamente na conversa entre moças e rapazes que se encontra o principal combate das Argonáuticas e a grande areteia de Jasão - em verdade, um ato de sedução pelo discurso.

${ }^{7} \mathrm{O}$ interesse de Jasão em demonstrar sua honestidade aparece ainda na dupla aparição do termo $\theta \varepsilon \dot{\mu \iota \varsigma}$ nos versos 984 (com referência às regras de ação dentro de templos) e 991, como obrigação de pagar uma graça com outra.

Organon, Porto Alegre, no 49, julho-dezembro, 2010, p.111 - 128 
narrador do conto "Famigerado" de Guimarães Rosa, porém com uma diferença, sutil mas importante: se no caso de Rosa percebemos que o narrador se utiliza da ambigüidade com o claro intuito de se safar; nas Argonáuticas não podemos afirmar ao certo se Jasão trama o que fala, ou se há aí algum nível de sinceridade ingênua do personagem. Essa dúvida, como pretendo demonstrar de agora em diante, permanecerá - tem de permanecer - sem resposta até o final do poema.

O Esônide ainda afirma que a fama de Medéia receberá honras de outros heróis além dele, bem como de suas respectivas mães e esposas que aguardam pelo retorno dos outros argonautas e que terão sua aflição sanada pela intervenção da virgem (992-5). Por fim, Jasão compara o auxílio de Medéia àquele prestado por Ariadne a Teseu segundo a lenda ${ }^{8}$. $\mathrm{O}$ modo como a história é contada é um cuidadoso exemplar da arte retórica: em primeiro lugar, Ariadne é

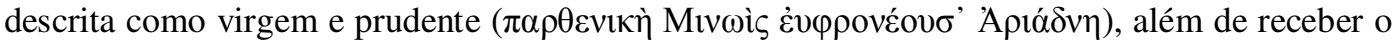
patronímico, já que a relação com o pai de Medéia também é importante. Marcando uma semelhança entre as duas, Jasão ainda vai além e recorda as origens de Pasífae, mãe de Ariadne, como descendente direta de Hélio. Essa relação estabelece mais que uma semelhança (ambas são virgens e supostamente prudentes), estabelece um elo de parentesco entre as duas jovens, o que resultaria em prêmios similares para a ajuda que cada uma pode dar, além de ganhar a simpatia de Medéia como ouvinte. Assim, Ariadne se torna o paradigma do destino de Medéia; desse modo, se ela, ao desobedecer o pudor paterno, conseguiu ajudar seu amado e fugir com ele, depois de obter o consentimento de seu pai Minos (como se depreende do verso 1000, غ̇ं $\varepsilon \dot{i}$

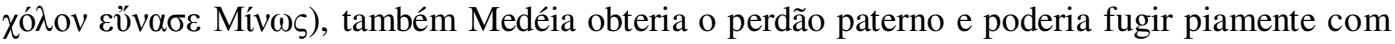
seu amado, estabelecendo uma doce união ( $\gamma \lambda \nu \kappa v ̀ v ~ \mu \varepsilon \tilde{i} \xi \alpha 1)$, segundo as palavras de Píndaro (Pyth. 4.223). É nesse espírito de promessa que Jasão recorda ambiguamente o fato de que Ariadne chegou a ser amada até pelos deuses em meio ao éter, numa referência que alude à sua transformação em constelação (vv. 1001-4). Por fim, o fechamento do pedido, com o adiado louvor à beleza da virgem.

Quanto ao texto, nada temos mais a comentar; somente percebemos que a fala de Jasão parece realizar a descrição de Píndaro, pois que a seqüência do texto revela a adesão de Medéia e sua recusa ao pudor paterno. Segundo Píndaro, Afrodite, nascida em Chipre,

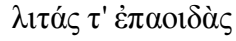

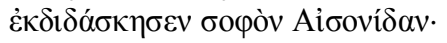

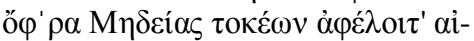

$\delta \tilde{\omega}$

preces e encantos
ensinou ao prudente Esônide;
pra que de Medéia tomasse o paterno pu-
dor (Pyth. $4.17-8)$

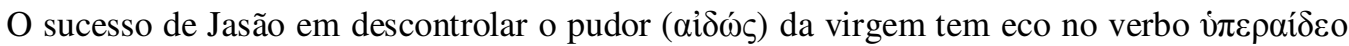
do verso 978, acima mencionado. No fim das contas, como já anunciado por Píndaro, é Jasão, e não Medéia, quem consegue seduzir com suas palavras. Só então podemos perceber que o mito de Ariadne não foi contado em sua totalidade: Jasão omite o fator fundamental de que, depois da fuga com Teseu, Ariadne foi abandonada por seu amado numa praia deserta (Cf. e.g. Catulo 64) e só então foi amada por Dioniso, que a encontrou sozinha no litoral. O jogo fica delicado porque Jasão omite um pequeno passo da história com uma ambigüidade ( $\dot{\alpha} \theta \alpha ́ v \alpha \tau o l ~ \varphi i ́ i \alpha v \tau o$, do verso 1002 pode ser lido com ou sem o sentido sexual), mas que, aos olhos do leitor, é mais um fator de recorrência e similaridade entre os amores de Medéia e de Ariadne. Ora, Medéia, depois de prestar o seu auxílio a Jasão e ser levada para Iolcos, também será abandonada: essa é a

\footnotetext{
${ }^{8}$ Do ponto de vista da narrativa, Jasão não conta um "mito" para Medéia, mas um fato histórico acontecido há pouco tempo (duas gerações, se considerarmos Hipsípile neta de Dioniso), o que constrói uma cronologia mitológica dentro da narrativa de Apolônio e o que leva o narrador a explicar a ausência de Teseu no grupo dos argonautas (já que algumas variantes do mito apresentavam-no como participante da expedição).
}

Organon, Porto Alegre, no 49, julho-dezembro, 2010, p.111 - 128 
trama básica que move a tragédia de Eurípides ${ }^{9}$. Mas, por ora, o nosso narrador parece não

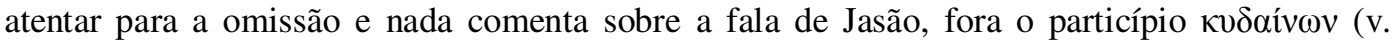
1007), previamente apontado. No silêncio de Jasão e do seu narrador, o leitor fica diante de uma ironia minuciosamente provocada pelo texto; não decorrente de alguma vagueza falha da narrativa de Apolônio, mas precisamente por causa das várias texturas com que constrói o texto sem fazer uma intervenção direta sobre o ponto de vista do leitor com o intuito de elucidar objetivos unívocos da sua narrativa. A questão irônica provocada pelo texto, portanto, é saber se a ironia trágica enunciada por Jasão ao aludir ao mito de Teseu e Ariadne foi ou não intencional até o seu limite. Afinal, Jasão já estaria pensando em abandonar Medéia desde o princípio da sua argumentação? Ou a série de coincidências supera o personagem, que também estaria tomado pela ironia trágica e, portanto, inconsciente da destruição que provocará sobre Medéia, mas também sobre si mesmo? A cena como um todo evoca a fala de Odisseu para Nausícaa em Od. 6.180-5, quando vemos o herói fazer uso do silêncio para tirar proveito da jovem perturbada e deixá-la entender esperançosamente mais do que deveria; porém aqui o processo de composição é muito mais sutil, na medida em que conta com outros trechos da obra e com o conhecimento prévio do leitor acerca dos mitos e obras aludidos.

No decorrer das Argonáuticas, nós ainda veremos mais duas alusões a Ariadne em 3.10741108 e 4.421-4. Com isso, notamos que o narrador insiste no tema para que o leitor perceba sua importância e talvez retorne ao cerne do problema da fala de Jasão. No primeiro caso (1.1074108), Medéia pede para Jasão narrar novamente a história de Ariadne; no entanto, na descrição que se segue, vemos que Jasão, tal como Medéia, também está apaixonado e tomado por um

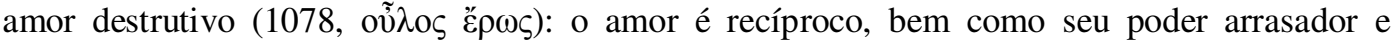
nefasto. Sabendo por parte do narrador que Jasão está realmente apaixonado, ouvimo-lo prometer novamente fugir com Medéia e narrar brevemente sobre Ariadne: basicamente sem acréscimos e com a renovada ênfase no fato de que Minos teria perdoado a filha e se conciliado com o genro; no mais, o resto da narrativa é adiado por parte de Jasão, que por ora não vê motivo para tais conversas. Novamente o narrador se cala quanto às intenções do silêncio de Jasão, ou, no máximo, aponta para sua sinceridade, apesar de mostrar que ele consegue acalmar

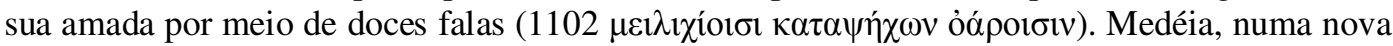

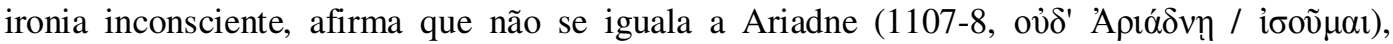
reforçando pela negação o caráter ingênuo de sua personagem, incapaz de perceber que as semelhanças são, em verdade, muito maiores do que ela poderia ter imaginado.

Na segunda alusão, tomamos conhecimento do manto que Jasão recebera de presente de Hipsípile em Lemnos; um símbolo e presente por seu poder persuasivo sobre as mulheres, sua grande virtude heróica no decorrer do poema. Assim, o presente recebido se torna novamente um presente para Apsirto, irmão de Medéia, a fim de enganá-lo e garantir a chance de que o casal consiga assassiná-lo e provocar um atraso na perseguição naval ordenada por Eetes. $\mathrm{O}$ trecho merece citação integral:

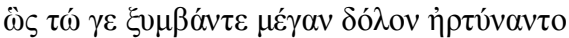

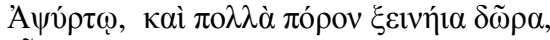

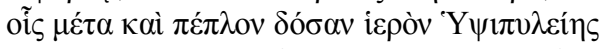

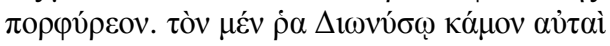

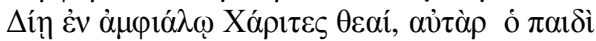

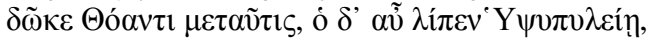

$$
\begin{aligned}
& \text { †ं } \delta \text { ' '̌́ }
\end{aligned}
$$

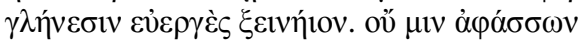

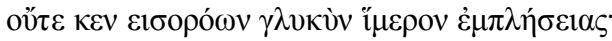

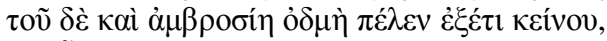

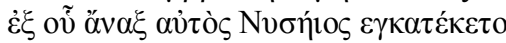

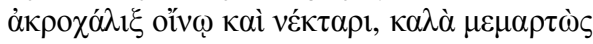

\footnotetext{
${ }^{9}$ Há ainda mais similaridades, como o fato de as duas colaborarem na morte do próprio irmão, o mito de felicidade após a morte, etc. (cf. Hunter, 1989, p. 208).
} 


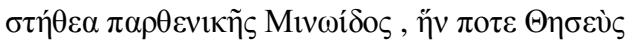

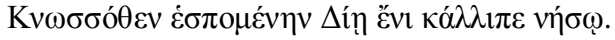

Então em concordância tramam grande dolo contra Apsirto, e ofertam dons hospitaleiros; dentre os presentes mandam o manto purpúreo de Hipsípile, que para Dioniso em Dia as divas Graças fabricaram; depois dera ao filho Toante, que o deixara para Hipsípile, e esta o deu ao Esônide com mais presentes hospitaleiramente. E nem mesmo apalpando e olhando apagarias teus doces desejos; pois ele sempre exala um odor imortal, desde que o rei dos Nísios ali se deitara leve de vinho e néctar, sobre os belos seios da virgem filha do rei Minos, que Teseu deixara em Dia após tê-lo seguido a Cnosso (Arg. 4.421-34).

O manto, passado de mãos em mãos, pertencera um dia ao próprio Dioniso para celebrar suas núpcias com Ariadne; mas essa cena nupcial é a que resulta num filho (com Ariadne), Toante, a quem o deus dera o manto, e que por sua vez o dera a Hipsípile, que o passou para Jasão, como símbolo de hospitalidade ${ }^{10}$. A descrição do manto mantém o observador em perpétuo desejo por causa do seu cheiro de vinho e néctar, além do suposto odor do ato sexual divino, expresso na nudez dos seios de Ariadne. Novamente uma ironia: os dois novos amantes, Jasão e Medéia, estão diante da imagem não revelada do abandono de Ariadne por Teseu. Se o narrador nada fala acerca do conhecimento dos personagens, por outro lado agora sabemos que ele próprio tem e demonstra ter o conhecimento sobre o resultado da primeira aventura amorosa de Ariadne. Caberia, afinal, ao leitor também ter esse conhecimento para formular sua interpretação do texto; e, se ele não houver percebido essa falha, agora pode retornar ao cerne do problema, com a insistente questão da consciência de Jasão em aberto.

Por isso, não devemos imaginar que o leitor de Apolônio desconhecesse o mito, já que ele também aparece em Calímaco, frags. 67, 110 e 610 Pfeiffer, nos hinos, 4.307-15; em Teócrito 2.45 e ss.; em Arato 71-3; dentre outros. Mas, depois dessas ambigüidades textuais, dessa trama irônica criada por Apolônio, nós não deveríamos ver uma leitura unívoca nessa trama de alusões e silêncios, nem interpretar rigidamente as intenções de Jasão, como faz Francis Vian ao defender que:

Esse precedente tem por natureza tocar Medéia, já que Pasífae é filha do Sol, bem como Eetes. Jasão adapta a lenda às necessidades de sua causa: ele garante que a jovem partiu com a permissão de seu pai e silencia sobre seu abandono graças a uma expressão habilmente ambígua (v. 1002) (Vian, 2002, p. 140, n. 1006).

Essa leitura elimina no personagem uma ambigüidade deliberada que só reforça o que venho chamando de ironia trágica desta épica. O que percebemos, depois de todo esse processo, é que

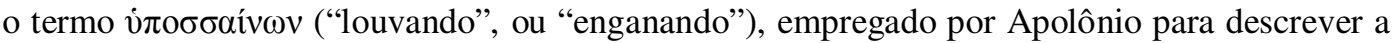
fala de Jasão, tem em sua equivocidade a mira certeira da escolha do narrador. E mais, os deslocamentos genéricos, ou cruzamento dos gêneros, operados pelo poeta não resultam numa mera estrutura literária vazia de sentido, ou numa defesa da arte pela arte, mas ao contrário constroem uma densa reflexão sobre os personagens com que nos deparamos: tal como Medéia precisa ser uma figura feminina que se move entre os dois pólos antagônicos e idealizados de Helena e Penélope (passando mesmo por Nausícaa, Circe e Calipso) no seu desenvolvimento ao

\footnotetext{
${ }^{10} \mathrm{Cabe}$ atentar que o que Medéia e Jasão intentam é exatamente quebrar as regras da hospitalidade pelas quais Jasão implorou no seu primeiro encontro, já que usarão os típicos presentes para enganar e matar Apsirto, o que também será um crime familiar, aumentado pelas atitudes ímpias do assassinato por trás e pelo tratamento dado ao corpo de Apsirto.
}

Organon, Porto Alegre, no 49, julho-dezembro, 2010, p.111 - 128 
longo dos livros 3 e 4, incorporando paradigmas da lírica amorosa, mas também apontando para a personagem trágica que é o seu futuro e o paratexto que a determina; do mesmo modo, Jasão não se enquadra plenamente nas figuras épicas pré-estabelecidas de Aquiles, Odisseu, ou Héracles, embora dialogue constantemente com todos eles, mas incorpora também a figura do jovem sedutor e do seu futuro nefasto que não pode deixar de irromper na cabeça do leitor a cada nova ação. É nesse constante movimento entre paradigmas genéricos que os personagens ganham força e não se reduzem ao ethos previamente estabelecido. Numa leitura desatenta ao texto de Apolônio, que busca demais num ou noutro texto auxiliar a leitura desejada, acabamos por apontar resultados ingênuos, como afirma Anatole Mori: "ele é 'sempre já desleal', e ela é "sempre já traída"' (2008, p. 189); de modo que nem mesmo o uso freqüente da tragédia resume os personagens da épica. Um verso de Valério Flaco poderia muito bem explicitar sinteticamente a guinada moral que se realiza em Medéia por decorrência da sedução do discurso de Jasão: "Cessit ab ore pudor propiorque impleuit Erinys" (Pudor sumiu da face, e Erínias possuíram-na, 7.462, trad. Márcio Gouvêa).

No entanto, ele funciona apenas como síntese do movimento complexo de Medéia ao longo do poema, um dos vários movimentos simultâneos que dão forma à narrativa. $\mathrm{O}$ que não podemos perder de vista é que, na leitura de Apolônio, são precisamente os diversos contornos desses movimentos, com suas diversas ambigüidades e silêncios, que dão a forma da sua nova épica.

\section{BIBLIOGRAFIA}

BOWRA, C. M. Pindari Carmina cum fragmentis. Oxford: Oxford University Press, 1947.

BRASWELL, Bruce Karl. A commentary on the fourth Pythian ode of Pindar. Berlin: Walter de Gruyter, 1988.

CAMPOS, Haroldo de. Ilíada de Homero. 2. ed. Organização Trajano Vieira. 2 vols. São Paulo: Arx, 2002.

FRAENKEL, Hermann. "Apollonius Rhodius as a Narrator in Argonautica 2.1-140" In: Transactions and Proceedings of the American Philological Association, Vol. 83, pp. 144-155, 1952

HUNTER, R. L. Apollonius Rhodius: Argonautica, book III. Cambridge: Cambridge University Press, 1989.

MORI, Anatole. The politics of Apollonius Rhodius Argonautica. Cambridge: Cambridge University Press, 2008.

MOZLEY, J. H. Valerius Flaccus. Translated by J. H. Mozley. Cambridge: Harvard University Press, 1936 (LCL 286).

RACE, William H. Apollonius Rhodius: Argonautica. Edited and translated bu William H. Race. Cambridge: Harvard University Press, 2008 (LCL 1).

RAGUSA, Giuliana. Fragmentos de uma deusa: a representação de Afrodite na lírica de Safo. Campinas: Unicamp, 2005.

VALÉRIO FLACO, Gaio. Cantos argonáuticos. Tradução do latim, introdução e notas de Márcio Meirelles Gouvêa Júnior. Coimbra: Universidade de Coimbra, 2010.

VIAN, Francis. Apollonios de Rhodes: Argonautiques. Paris: Les Belles Lettres, 2002. 